\section{Pacific Northwest}

National Laboratory

Operated by Battelle for the

U.S. Department of Energy

\title{
Effect of Dietary Intake of Stable Iodine on Dose-per-unit-intake Factors for 99Tc
}

D.J. Strom

September 2003

Prepared for the U.S. Department of Energy under Contract DE-AC06-76RL01830 


\title{
DISCLAIMER
}

This report was prepared as an account of work sponsored by an agency of the United States Government. Neither the United States Government nor any agency thereof, nor Battelle Memorial Institute, nor any of their employees, makes any warranty, express or implied, or assumes any legal liability or responsibility for the accuracy, completeness, or usefulness of any information, apparatus, product, or process disclosed, or represents that its use would not infringe privately owned rights. Reference herein to any specific commercial product, process, or service by trade name, trademark, manufacturer, or otherwise does not necessarily constitute or imply its endorsement, recommendation, or favoring by the United States Government or any agency thereof, or Battelle Memorial Institute. The views and opinions of authors expressed herein do not necessarily state or reflect those of the United States Government or any agency thereof.

\author{
PACIFIC NORTHWEST NATIONAL LABORATORY \\ operated by \\ BATTELLE \\ for the \\ UNITED STATES DEPARTMENT OF ENERGY \\ under Contract DE-AC06-76RL01830
}

Ty 
PNNL-14429

UC-610

\section{Effect of Dietary Intake of Stable Iodine on Dose-per-unit-intake Factors for ${ }^{99} \mathrm{Tc}$}

D. J. Strom

September 2003

Prepared for the Office Civilian Radioactive Waste Management U.S. Department of Energy

under Contract DE-AC06-76RLO 1830

Pacific Northwest National Laboratory

Richland, Washington 99352 


\section{Executive Summary}

It is well-known that the human thyroid concentrates iodine more than 100 times the concentration in plasma. Also well-known is the fact that large amounts of stable iodine in the diet can limit thyroid uptake of total iodine; this is the basis for administering potassium iodide following a release of radioiodine from a nuclear reactor accident or nuclear weapon detonation. Many researchers have shown enhanced concentrations of both organic and inorganic iodine in saliva and breast milk.

Technetium-99 is a long-lived (231,000 year half-life) radionuclide of concern in the management of high-level radioactive waste. There is no doubt that ${ }^{99} \mathrm{Tc}$, if it is in groundwater, will be found in the chemical form of pertechnetate, ${ }^{99} \mathrm{TcO}_{4}{ }^{-}$. Pertechnetate is a large anion, almost identical in size to iodide, $\mathrm{I}^{-}$. The nuclear medicine literature shows that pertechnetate concentrates in the thyroid, salivary glands, and lactating breast in addition to the stomach, liver, and alimentary tract as currently recognized by the International Commission on Radiological Protection (ICRP). The fact that large intakes of stable iodine $\left({ }^{127} \mathrm{I}\right)$ in the diet limit uptake of iodine by the thyroid leads one to generalize that stable iodine in the diet may also limit thyroid uptake of pertechnetate. While there is at least one report that iodine in the diet blocks uptake of ${ }^{99 \mathrm{~m}} \mathrm{TcO}_{4}{ }^{-}$by the thyroid and salivary glands (which have the same $\mathrm{Na} / \mathrm{I}$ symporter, the biochemical concentration mechanism), the level of protective effect seen for blocking radioactive iodine is not expected for ${ }^{99} \mathrm{TcO}_{4}{ }^{-}$because pertechnetate does not become organically bound in the thyroid and thus is not retained for months the way iodide is.

While it does account for Tc concentration in the thyroid, the existing ICRP biokinetic model for technetium does not take enhanced concentrations in salivary gland and breast tissue into account. From the survey of the nuclear medicine literature, it is not possible to compute the effect of stable iodine in the diet on the dose per unit intake factors for ${ }^{99} \mathrm{Tc}$ without developing an improved biokinetic model for technetium. Specific experiments should be designed to quantitatively evaluate ${ }^{99} \mathrm{TcO}_{4}{ }^{-}$metabolism, excretion, and secretion, as well as to evaluate its chemical toxicity

It is recommended that the ICRP reexamine its biokinetics models for Tc based on nuclear medicine data that have accumulated over the years. In particular, the ICRP ignores the lactation pathway, the enhanced concentration of Tc in breast and breast milk, and enhanced concentration of Tc (and I) in the salivary glands as well as in the thyroid. The ICRP should also explicitly incorporate the effect of stable iodine in the diet into both its models for iodine and technetium. The effect of concentration of Tc in breast milk needs further study for dosimetric implications to nursing infants whose mothers may ingest ${ }^{99} \mathrm{TcO}_{4}{ }^{-}$from groundwater sources. The ICRP should also investigate the possibility of enhanced concentration of both I and Tc in the nonlactating female breast.

To do these re-evaluations of biokinetic models, new experiments designed specifically to evaluate these questions concerning the biokinetics of Tc and I are needed. 


\section{Contents}



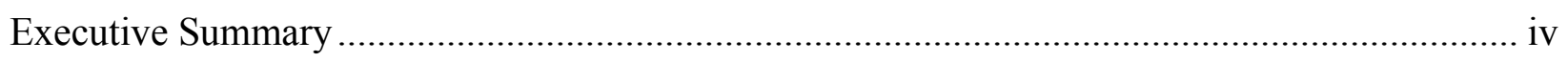





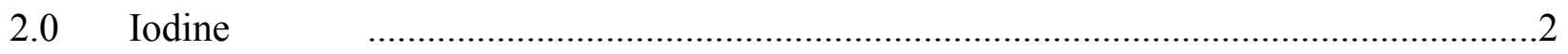

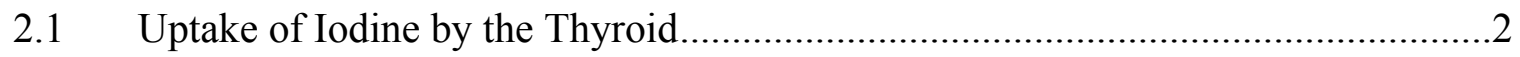



2.3 Retention Half-time of Iodine in the Thyroid ...............................................



3.1 Chemical Speciation of Technetium in the Environment ....................................5

3.2 The ICRP Biokinetic Models for Technetium ...............................................6

3.3 Technetium Concentrates in the Salivary Glands ..........................................

3.4 Technetium Concentrates in the Thyroid .........................................................9

3.5 Technetium Concentrates in the Breast and Breast Milk.....................................

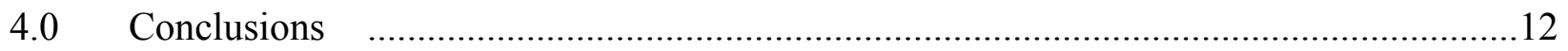










\subsection{Introduction}

The effective dose or effective dose equivalent due to intakes of radioactive ${ }^{129}$ I depends on what fraction of iodine in the bloodstream is taken up by the thyroid, the retention half-time for the iodine that is taken up by the thyroid, and the thyroid mass. The fraction of iodine taken up by the thyroid varies inversely with the dietary intake of stable, nonradioactive iodine $\left({ }^{127} \mathrm{I}\right)$. If there is significant stable iodine in drinking water or another dietary source, uptake fractions will be lower, and dose per unit intake (i.e., rems/nCi or $\mathrm{Sv} / \mathrm{Bq}$ ) will be correspondingly lower.

Technetium-99, if found in groundwater, will almost exclusively be found as ${ }^{99} \mathrm{TcO}_{4}{ }^{-}$ (pertechnetate). Extensive nuclear medicine use of pharmaceutical-grade ${ }^{99 m} \mathrm{TcO}_{4}{ }^{-}$has shown that, like iodine, it is concentrated by the thyroid gland and salivary glands, and preferentially secreted in breast milk and saliva. It follows that the dose per unit intake of ${ }^{99} \mathrm{Tc}$ will also be lowered by intake of large amounts of stable iodine in the diet. In a study that examined how thyroid pertechnetate uptake with and without thyroid-stimulating hormone (TSH) suppression changes as a function of increasing iodine supply, Reinhardt et al. conclude that "the influence of TSH on the thyroid pertechnetate uptake seems to be secondary compared with the influence of the iodine supply" (Reinhardt et al. 1998). With lowered uptake comes lower dose.

This paper is a literature review of the dosimetry of intakes of technetium, with the goal of examining the significance of stable iodine in the diet on technetium dosimetry, and suggesting research needs to fill the gaps. It examines similarities and differences of technetium and iodine in the context of dosimetry. 


\subsection{Iodine}

\subsection{Uptake of Iodine by the Thyroid}

A literature search was undertaken to find the correlation of thyroid uptake fraction and thyroid retention time for iodine as a function of stable iodine intake. It is reasonable to hypothesize that there is non-zero covariance (or contravariance) of thyroid uptake fraction, thyroid mass, and iodine retention time in the thyroid with dietary intake of stable iodine. The first formal study of the effects of these three variables (Dunning, Jr. and Schwarz 1981) assumed that each was independent of the other two, an assumption that is questionable, and did not examine the dependence of these variables on stable iodine intake from drinking water and diet. The most comprehensive review of iodine metabolism published to date is available on the internet (National Cancer Institute 1997). Recently, other researchers have assumed that thyroid mass and iodine uptake fraction are "highly correlated" (they use a correlation coefficient of 0.9 ) to develop age-specific uncertainty of the ${ }^{131}$ I ingestion dose conversion factor (Harvey, Hamby, and Benke 2003). Harvey et al. don't appear to analyze the covariance of thyroid retention time with uptake fraction and thyroid mass.

Figure 1 shows the equivalent dose per unit intake via ingestion for various adult organs and tissues using the newest International Commission on Radiological Protection (ICRP) biokinetic models, as computed by IMBA-Expert (James 2003). With the ICRP's default tissue weighting factor $w_{T}=0.05$, the default fractional absorption of I from the gut, $f_{1}$, of 1.0, the default thyroid uptake of $30 \%$, and the default half-time in the thyroid of 80 days, the equivalent dose to the thyroid is 4,900 times greater than the next most highly exposed tissue. Note that the breast receives less dose than almost any other tissue, and that the salivary glands are not listed. These two tissues probably receive much larger doses than indicated in the ICRP model, as shown below for Tc. 
I-129 Ingestion from IMBA-Expert USDOE Phase II (beta+)

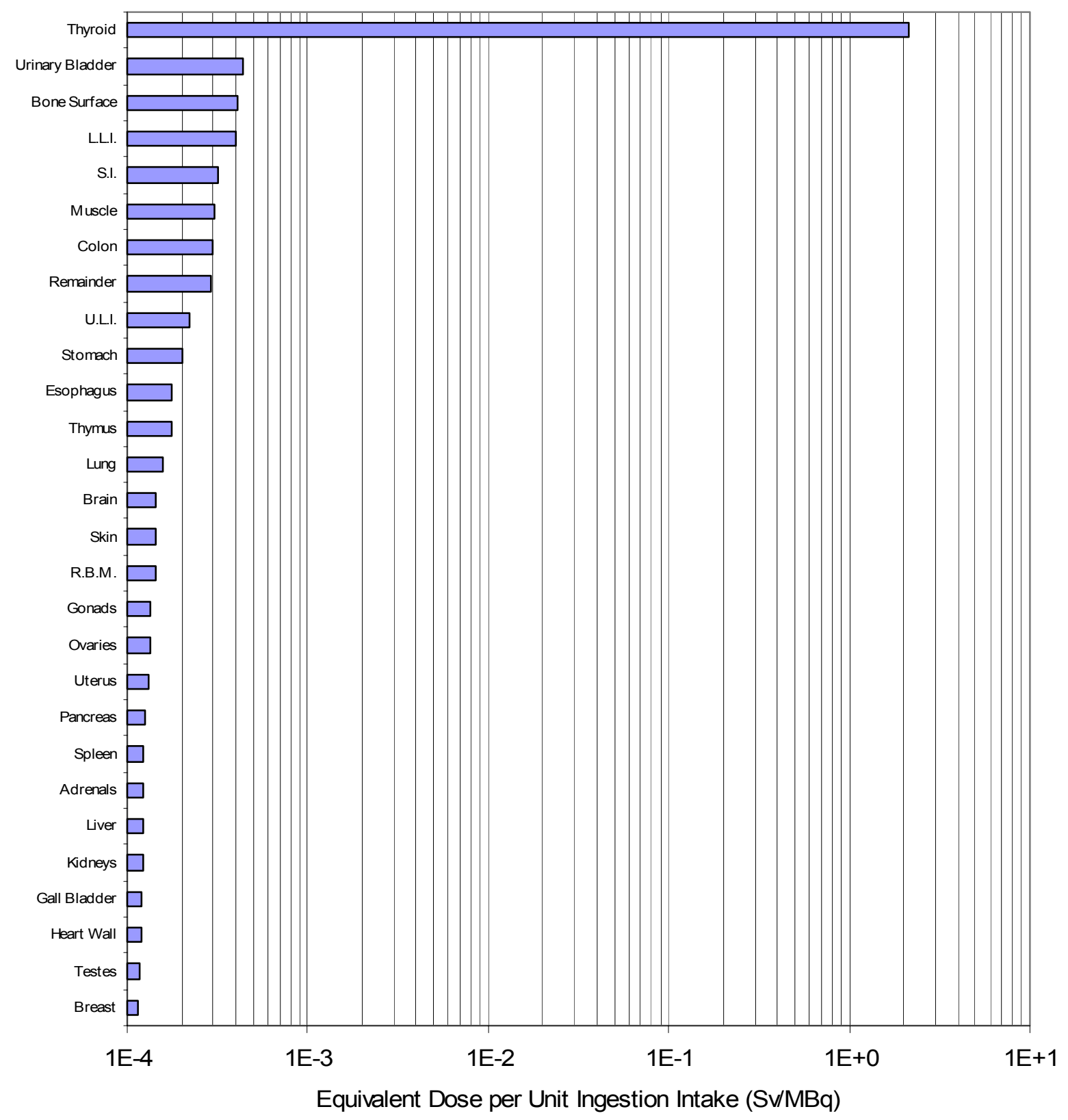

Figure 1. Equivalent dose-per-unit-intake to various organs and tissues in an adult from ${ }^{129} \mathrm{I}$ ingestion intake, as computed by IMBA-Expert 3.0.64.

\subsection{Thyroid Blocking by Intake of Stable Iodine}

A simple mathematical description of iodine uptake is given by 


$$
U=\frac{I}{D+R}
$$

where

$U=$ fractional thyroid iodine uptake

$I=$ thyroid ${ }^{127}$ I uptake rate $=60$ to $70 \mu \mathrm{g} \mathrm{d}^{-1}$

$D=$ dietary ${ }^{127}$ I intake per day

$R=$ iodine recycled from the thyroid $=0.8$ to $0.9 I$ (National Cancer Institute 1997;

Stather and Greenhalgh 1983).

This equation is plotted in Figure 2 assuming a daily thyroid mass uptake of $70 \mu \mathrm{g}$ and a recycling fraction of 0.85 . At the level of potassium iodide $(\mathrm{KI})$ currently recommended in the USA for thyroid blocking in case of an emergency, $130 \mathrm{mg}$ KI (i.e., $100 \mathrm{mg}$ of I) per day (U.S. Food and Drug Administration (FDA) 2001), the fractional uptake is $0.07 \%$. It must be noted, however, that simply assuming uniform dilution of any intake of iodine in a $70 \mathrm{~kg}$ person with a $20 \mathrm{~g}$ thyroid would result in a fractional uptake of $20 / 70,000=0.029 \%$, probably a limiting value. Furthermore, blocking the thyroid results in no reduction of dose to other tissues, so there is a limiting value of thyroid blocking that results in any meaningful dose reduction.

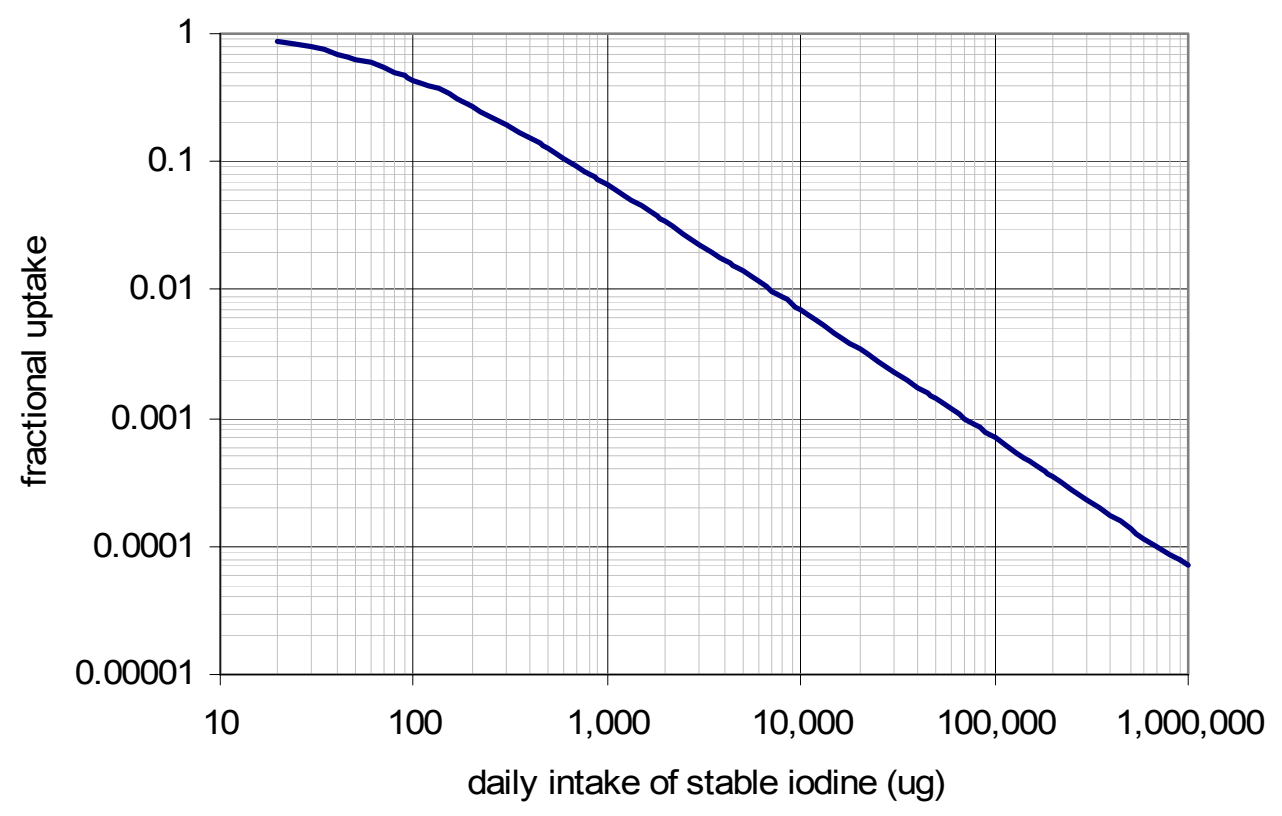

Figure 2. Fractional uptake of dietary iodine as a function of the daily intake of stable iodine.

Data on stable ${ }^{127}$ I levels in the ground water in the vicinity of Yucca Mountain appear to be about $5 \mu \mathrm{g} / \mathrm{L}$ (Moeller 2003). Consuming $2 \mathrm{~L}$ of water per day, a person ingests $10 \mu \mathrm{g} /$ day of iodine from groundwater. From Figure 2 it can be seen that such an intake doesn't suppress the fractional uptake by the thyroid. However, as shown by Moeller (2003), the simple dilution of groundwater iodine by stable ${ }^{127} \mathrm{I}$ from other dietary sources places an upper bound on doses due to intake of ${ }^{129} \mathrm{I}$. 
The presumption here is that large intakes of stable ${ }^{127}$ I will reduce uptake of not only the thyroid, but also the salivary glands and the breast.

\subsection{Retention Half-time of Iodine in the Thyroid}

The retention half-time for iodine in the thyroid increases with age, from 15 to 25 days for newborns, up to average values of about 80 days in adults, with wide variability (National Cancer Institute 1997). The two-step process of 1) vigorous concentration of iodine in the thyroid by the $\mathrm{Na}$ /I symporter transport system (Van Sande et al. 2003) and the "organification" (covalent binding of iodine to thyroglobulin, resulting in an iodinated thyroglobulin) of the iodine once in the thyroid lead to the high concentration and long retention, respectively (Meller and Becker 1998).

\subsection{Technetium}

A review and analysis of the literature on ${ }^{99} \mathrm{TcO}_{4}{ }^{-}$intake and uptake follows. The magnitude of reduction of effective dose and effective dose equivalent as a function of stable iodine intake in the diet is evaluated based on this information.

\subsection{Chemical Speciation of Technetium in the Environment}

"Some radionuclides, such as technetium, uranium, and plutonium, may be present in more than one oxidation state in the environment. The adsorption and precipitation behavior of different oxidation states of a particular radionuclide are usually very different. For example, in environmental systems, the most stable oxidation states of technetium are +7 and +4 under oxidizing and reducing geochemical conditions, respectively. The chemical behavior of technetium in these two oxidation states differs drastically. Dissolved Tc(VII) exists as pertechnetate anion, $\mathrm{TcO}_{4}{ }^{-}$, over the complete $\mathrm{pH}$ range of natural waters under oxic conditions. Because the pertechnetate anion is highly soluble and is not strongly sorbed, it is highly mobile in most oxidizing systems. Under reducing conditions, however, Tc(IV) exists as hydrolyzed cations and is relatively immobile in the absence of strongly complexing ligands.

Technetium(IV) is highly sorbed and forms the sparingly soluble $\mathrm{TcO}_{2} \cdot \mathrm{nH}_{2} \mathrm{O}$ solid" (Robertson et al. 2003). This statement can be summarized as, 'If technetium is mobile, that is, if it's in the water, it's in the chemical form of pertechnetate ion. Conversely, if technetium is in the form of $\mathrm{TcO}_{2}$, it's insoluble.

Therefore, "in oxidized waters, such as those at the potential U.S. Yucca Mountain repository, $\mathrm{Tc}(\mathrm{VII})$, as pertechnetate ion $\left(\mathrm{TcO}_{4}{ }^{-}\right)$, is the dominant Tc species. A large anion, $\mathrm{TcO}_{4}{ }^{-}$, is highly soluble and mobile in water" (Langmuir 1997).

For purposes of this report, then, any technetium taken in from groundwater is assumed to be in the chemical form of pertechnetate.

In a report on research needs for radiation protection, the National Council on Radiation Protection and Measurements (NCRP) stated that technetium "has an extremely low affinity for soil and sediment particles, and an extremely high degree of bioavailability. Making this 
radionuclide even more challenging is that is has been identified as presenting a higher risk as a chemical toxicant than as a radioactive material" (National Council on Radiation Protection and Measurements (NCRP) 1993). "In terms of specifics, it interacts as a sulfur analog in metabolic and chemical processes. This can lead to the metabolic dysfunction and death of the exposed organism. Evidence indicates that this interaction is most pronounced with the complex proteins used in electron transport; thus in the case of plants, photosynthesis and protein metabolism are affected. While there is a wealth of information for the soil-plant system, its implications for the subsequent food pathways have been neglected and require attention" (NCRP 1993).

\subsection{The ICRP Biokinetic Models for Technetium}

The early ICRP work quotes the fractional absorption of Tc from the gut, $f_{1}$, as 0.5 for persons over age 1, and 1.0 for persons under age 1 (International Commission on Radiological Protection (ICRP) 1993). More recently, the values of $f_{1}$ are given as 1 for age 3 months and 0.8 for age above 3 months (International Commission on Radiological Protection (ICRP) 1995).

The ICRP recognizes that "technetium administered intravenously as pertechnetate is concentrated in the thyroid, gastrointestinal tract and liver" (International Commission on Radiological Protection (ICRP) 1993). In 1980, the ICRP

"adopted a simplified model to describe the retention of technetium after entry into body fluids. Of technetium leaving the transfer compartment 0.04 is assumed to be translocated to the thyroid and retained with a half-time of 0.5 days. Further fractions, 0.1 and 0.03 , are assumed to be translocated to the stomach wall and liver, respectively. The remaining fraction is assumed to be uniformly distributed throughout all organs and tissues of the body other than they thyroid, $0.75,0.20$, and 0.05 are assumed to be retained with biological half-times of 1.6, 3.7, and 22 days, respectively. For technetium the biological half-time in the transfer compartment is taken to be 0.02 days. No further data appear to have been published which suggest these biokinetics parameters need to be modified and they are therefore adopted here... A urinary to fecal excretion ratio of $1: 1$ is assumed for technetium that has entered the transfer compartment" (International Commission on Radiological Protection (ICRP) 1993).

The biokinetics data for the adult are adopted for infants and children. 
Tc-99 Ingestion f1 = 0.8 Results from IMBA-Expert USDOE Phase II (beta+)



Figure 3. Equivalent dose-per-unit-intake for ingestion of ${ }^{99} \mathrm{TcO}_{4}{ }^{-}$by an adult with $f_{1}=0.8$ using ICRP 68 models and default parameters, done by IMBA-Expert USDOE Edition 3.0.64.

A plot of the results of the ICRP models described above is shown in Figure 3. There is no calculation for the salivary glands, and the breast receives no enhanced dose when compared to all other tissues not specifically listed in Figure 3.

\subsection{Technetium Concentrates in the Salivary Glands}

Technetium as pertechnetate concentrates in the salivary glands and thyroid, and is routinely used for imaging of these tissues because ${ }^{99 \mathrm{~m}} \mathrm{TcO}_{4}{ }^{-}$gives less dose, is more readily available, and produces better images than the best alternative radionuclide of iodine, ${ }^{123} \mathrm{I}$. Some recent literature has quantified the salivary gland uptake. Before high dose radioiodine therapy, "[I]n 25 control patients, uptake of ${ }^{99 \mathrm{~m}} \mathrm{Tc}$-pertechnetate was $0.45 \%+/-0.16 \%$ and $0.42 \%+/-0.16 \%$ in parotid and submandibular glands, respectively" and "[i]n 25 amifostine-treated patients, uptake of ${ }^{99 \mathrm{~m}}$ Tc-pertechnetate was $0.46 \%+/-0.16 \%$ and $0.43 \%+/-0.17 \%$ in parotid and submandibular glands, respectively" (Bohuslavizki et al. 1998). In another study, these authors also showed that amifostine protected the salivary glands when administered before and during high dose radioiodine therapy.

The mass of pairs of major salivary glands in adult males and adult females is given in Table 1, along with the uptake fractions. The concentration factors are \% uptake divided by $\%$ body mass, and the salivary glands average an 8.9-fold concentration factor. 
Table 1. Mass of salivary glands, thyroid gland, and breasts in adults and reported uptakes of ${ }^{99 \mathrm{~m}} \mathrm{TcO}_{4}{ }^{-}$. Concentration factors are (\% uptake) $/(\%$ of body mass $)$. Concentration factor for lactating breasts calculated in this work.

\begin{tabular}{|c|c|c|c|c|c|c|c|c|c|}
\hline Glands & $\begin{array}{c}\text { Adult Male } \\
\text { Mass (g) } \\
\text { (ICRP } \\
2003 \text { ) }\end{array}$ & $\begin{array}{c}\text { Adult } \\
\text { Female } \\
\text { Mass (g) } \\
\text { (ICRP } \\
\text { 2003) }\end{array}$ & $\begin{array}{c}\text { Adult } \\
\text { Male \% } \\
\text { uptake }\end{array}$ & $\begin{array}{c}\text { Adult } \\
\text { Female } \\
\% \text { uptake }\end{array}$ & $\begin{array}{c}\text { Adult } \\
\text { Male \% of } \\
\text { Body } \\
\text { Mass }\end{array}$ & $\begin{array}{c}\text { Adult } \\
\text { Female \% } \\
\text { of Body } \\
\text { Mass }\end{array}$ & $\begin{array}{l}\text { Adult } \\
\text { Male } \\
\text { Conc. } \\
\text { Factor }\end{array}$ & $\begin{array}{l}\text { Adult } \\
\text { Female } \\
\text { Conc. } \\
\text { Factor }\end{array}$ & Source \\
\hline Parotid (2) & 50 & 41 & $0.45 \%$ & $0.45 \%$ & $0.068 \%$ & $0.068 \%$ & 6.6 & 6.6 & Bohuslavizki 1998 \\
\hline Submaxillary (2) & 25 & 21 & $0.42 \%$ & $0.42 \%$ & $0.034 \%$ & $0.035 \%$ & 12.3 & 12.0 & Bohuslavizki 1998 \\
\hline Sublingual (2) & 10 & 8 & $0.17 \%$ & $0.16 \%$ & $0.014 \%$ & $0.013 \%$ & 12.3 & 12.0 & scaled to submaxillary \\
\hline Salivary Glands Total & 85 & 70 & $1.04 \%$ & $1.03 \%$ & $0.116 \%$ & $0.117 \%$ & 8.9 & 8.8 & - \\
\hline Thyroid & 20 & 17 & $3.00 \%$ & $3.00 \%$ & $0.027 \%$ & $0.028 \%$ & 110 & 106 & Meller \& Becker 1998 \\
\hline Breasts & 25 & 500 & & & $0.034 \%$ & $0.83 \%$ & & & \\
\hline Total Body & 73,000 & 60,000 & & & $100 \%$ & $100 \%$ & & & ICRP 2003 \\
\hline Body Remainder & 72,895 & 59,913 & $95.96 \%$ & $95.97 \%$ & $99.86 \%$ & $99.86 \%$ & 0.96 & 0.96 & - \\
\hline Breasts (lactating) & & 553 & & $1.52 \%$ & & $0.92 \%$ & & 1.65 & This work \\
\hline $\begin{array}{l}\text { Body Remainder } \\
\text { (lactating) }\end{array}$ & & 59,360 & & $94.45 \%$ & & $98.93 \%$ & & 0.95 & - \\
\hline
\end{tabular}




\subsection{Technetium Concentrates in the Thyroid}

There is considerable use of ${ }^{99 \mathrm{~m}} \mathrm{TcO}_{4}{ }^{-}$for thyroid imaging because it concentrates in the thyroid. Cellular studies of the human sodium/iodide symporter have shown similar increases in uptake for ${ }^{123} \mathrm{I}_{\text {and }}{ }^{99 \mathrm{~m}} \mathrm{TcO}_{4}^{-}$(350-fold, and 340-fold, respectively) (Petrich et al. 2002). German researchers report that, "[d]ue to comparable molecular sizes of ${ }^{99 \mathrm{~m}} \mathrm{TcO}_{4}{ }^{-}\left(V=4.05 \times 10^{-23}\right)$ and iodine $\left(V=4.22 \times 10^{-23}\right)$, pertechnetate is being transported by the $\mathrm{Na}^{+} / \mathrm{I}^{-}$symporter into the follicular thyroid cell, but kinetics differ from iodine isotopes, as ${ }^{99 \mathrm{~m}} \mathrm{TcO}_{4}{ }^{-}$is not organified in the gland. The thyroid uptake of ${ }^{99 \mathrm{~m}} \mathrm{TcO}_{4}{ }^{-}$increases within the first 15 minutes after intravenous application (influx $>$ efflux), exhibits a plateau phase between 15 and 30 minutes where in- and efflux are balanced and decreases again after 30 minutes. The absolute uptake of ${ }^{99 \mathrm{~m}} \mathrm{Tc}$ pertechnetate is small, ranging from $0.3-3 \%$ of the administered activity in countries with sufficient iodine supply to $1.2-7 \%$ in iodine deficiency areas" (Meller and Becker 1998).

The key implication of the Meller and Becker analysis is that, because the ${ }^{99 \mathrm{~m}} \mathrm{TcO}_{4}{ }^{-}$is not organified, it doesn't have the long retention time in the thyroid that iodine does. And since ${ }^{99} \mathrm{TcO}_{4}{ }^{-}$is rapidly eliminated from the body, the pool available for recycling back into the thyroid dwindles rapidly.

Nonetheless, as shown in Table 1, accumulation of $3 \%$ of an administered dose of ${ }^{99 \mathrm{~m}} \mathrm{TcO}_{4}{ }^{-}$in the thyroid amounts to a more than 100-fold concentration enhancement over other tissues. In terms of effective dose or effective dose equivalent, using a tissue weighting factor of $w_{\text {thyroid }}=$ 0.05 , the relative contributions of the thyroid dose to the effective dose for an administration of 1 $\mathrm{Bq} / \mathrm{kg}$ is roughly $(0.05)(100 \mathrm{~Bq} / \mathrm{kg})$. The contribution of all other tissues is roughly $(0.95)(0.97 \mathrm{~Bq} / \mathrm{kg})$. The ratio of thyroid contribution to the contribution from all other tissues is about $5: 1$.

\subsection{Technetium Concentrates in the Breast and Breast Milk}

One study of a nursing mother measured $10.8 \%$ of total injected ${ }^{99 \mathrm{~m}} \mathrm{TcO}_{4}{ }^{-}$activity excreted in breast milk (Ahlgren et al. 1985). Mountford and Coakley surveyed seven cases of ${ }^{99 \mathrm{~m}} \mathrm{TcO}_{4}{ }^{-}$ administration, and found a mean of $7.5 \%$ ingested by infants, with a range of $0.13 \%$ to $33 \%$ (Mountford and Coakley 1989). Another report showed a total fraction of $2.5 \%$ excreted with a decay-corrected biologic half-time of 5.2 hours (Hedrick, Di Simone, and Keen 1986). A South African report of 11 patients showed an average of $12.18 \pm 7.68 \%$ of administered activity appearing in milk (range: $0.56 \%$ to $24.36 \%$ ), with half-times of $4.15 \pm 1.73$ hours (range: 2.23 8.26) (Rubow et al. 1994). A value is $10 \%$ is chosen in this report to be representative of the published values.

There are anecdotal case reports of seeing enhanced concentrations of ${ }^{99 \mathrm{~m}} \mathrm{TcO}_{4}{ }^{-}$in the breasts of nursing mothers, as would be obvious from the above data.

For a pure beta emitter like ${ }^{99} \mathrm{Tc}$, a reasonable approximation is to assume that the energy emitted in a tissue is absorbed in a tissue. The rate at which energy is emitted in a tissue is directly proportional to the concentration of a radionuclide in the tissue. 
The average concentration in the breast $\bar{C}$, is the mass-weighted average of concentration in breast parenchymal tissue $\left(C_{\text {breast }}\right)$ and concentration in breast milk $\left(C_{\text {milk }}\right)$ produced and stored in that tissue. This average for dosimetric purposes would be

$$
\bar{C}_{\text {breast }}=\frac{C_{\text {milk }} m_{\text {milk }}+C_{\text {breast }} m_{\text {breast }}}{m_{\text {milk }}+m_{\text {breast }}},
$$

where $C$ denotes concentration $(\mathrm{Bq} / \mathrm{kg})$ and $m$ denotes mass $(\mathrm{kg})$. It is difficult to infer the dose enhancement to the breast of the lactating woman without simultaneous measurements of concentration in both the body and the milk.

One indirect approach is to estimate the parameters needed for solving Equation (2) from reference values. The mass of milk in the breast is assumed to be time-varying, increasing from zero to a maximum between feedings, and then decreasing to zero again, with an average of 0.5 of the maximum. Assuming 8 feedings per day and a daily milk production of $850 \mathrm{~mL}$ (International Commission on Radiological Protection (ICRP) 1975), the average milk mass becomes

$$
m_{\text {milk }}=\frac{(850 \mathrm{~mL} / \text { day })(0.5)}{(1000 \mathrm{~mL} / \mathrm{kg})(8 \text { feedings } / \text { day })}=0.053 \mathrm{~kg} .
$$

The non-lactating breast mass is $m_{\text {breast }}=0.5 \mathrm{~kg}$ (International Commission on Radiological Protection (ICRP) 2002).

The average concentration of $\mathrm{TcO}_{4}{ }^{-}$in breast milk depends on whether there has been an acute intake, as in a radiopharmaceutical administration of ${ }^{99 \mathrm{~m}} \mathrm{TcO}_{4}{ }^{-}$, or whether there has been a chronic intake, as might be the case from ${ }^{99} \mathrm{TcO}_{4}{ }^{-}$in groundwater that is used as drinking water. In the former case, concentration drops rapidly with a half-time of 4-5 hours. In the latter case, which is of interest here, the concentration will reach an equilibrium value of $10 \%$ of the daily ${ }^{99} \mathrm{Tc}$ intake diluted in $850 \mathrm{~mL}$ of milk. Thus the relative concentration of ${ }^{99} \mathrm{TcO}_{4}{ }^{-}$can be computed assuming the woman's body mass is $60 \mathrm{~kg}$ (Table 1$)$, as

$$
\frac{C_{\text {milk }}}{C_{\text {body }}}=\frac{(0.1) /(0.85 \mathrm{~kg})}{(0.9) /(59.15 \mathrm{~kg})}=7.73 \text {. }
$$

Using Equation (2) with a 7.73-fold bioconcentration of ${ }^{99} \mathrm{TcO}_{4}{ }^{-}$in milk $\left(C_{\text {milk }}=7.73 C_{\text {breast }}\right)$, $\bar{C}=1.65$, significantly larger than $C_{\text {breast }}$, the concentration in the parenchymal tissue of the breast of the nursing mother. For a pure beta-emitter like ${ }^{99} \mathrm{Tc}$, this increased concentration increases the dose to breast by the same factor when compared to other soft tissues.

The value of 1.65 is a lower bound, because is assumes no enhanced concentration in the soft tissues of the breast, only enhanced concentration in the milk, a simplifying assumption since at least a portion of the mammary parenchymal tissue must also have enhanced concentrations in order to produce milk with enhanced concentrations. On the other hand, the mass of the nonlactating breast may be significantly lower than the mass of the lactating breast just after nursing, reducing the value. This research was not able to establish which of the two effects predominates.

It is unknown what concentration enhancement occurs, if any, in non-lactating breast tissue. 
Assuming no change in the daily intake of water by nursing mothers when compared to nonnursing women, the daily intake by the nursing mother of ${ }^{99} \mathrm{TcO}_{4}{ }^{-}$is $(2 \mathrm{~L} /$ day $)\left(C_{\text {groundwater }}\right.$ $[\mathrm{Bq} / \mathrm{L}])$.

The dose to the nursing newborn from enhanced concentrations of ${ }^{99} \mathrm{Tc}$ in breast milk would be increased. The daily intake by the nursing infant is $10 \%$ of the mother's intake, or perhaps $10 \%$ of the mother's intake multiplied by the mother's uptake from the gut $\left(=0.1 f_{1}\right)$, that is, $8 \%$ if $f_{1}$ is 0.8 . If the infant's mass is less than $10 \%$ or $8 \%$ of the mother's mass, i.e., less than $6 \mathrm{~kg}(13.2$ pounds) or $4.8 \mathrm{~kg}(8.8 \mathrm{lb})$, respectively, in this calculation, then the activity taken in per unit body mass is higher for the infant than for the mother. If higher values of ${ }^{99} \mathrm{TcO}_{4}{ }^{-}$concentration in breast milk are used, then infant intakes will be proportionately higher. 


\subsection{Conclusions}

It is well-known that the human thyroid concentrates iodine over 100-fold what is in plasma. Also well-known is the fact that large amounts of stable iodine in the diet can limit thyroid uptake of total iodine. There are also a host of papers showing enhanced concentrations of both organic and inorganic iodine in saliva and breast milk, although those data are not reviewed here.

Technetium-99 in groundwater will be found in the form of pertechnetate ${ }^{99} \mathrm{TcO}_{4}{ }^{-}$. The nuclear medicine literature shows that pertechnetate concentrates in the thyroid, salivary glands, and lactating breast in addition to the stomach, liver, and alimentary tract as currently recognized by the ICRP. The fact that large intakes of stable iodine $\left({ }^{127} \mathrm{I}\right)$ in the diet limit uptake of iodine by the thyroid leads one to generalize that stable iodine in the diet may also limit thyroid uptake of pertechnetate. While there is at least one report that iodine in the diet blocks uptake of ${ }^{99 m} \mathrm{TcO}_{4}{ }^{-}$ by the thyroid and salivary glands (which have the same $\mathrm{Na} / \mathrm{I}$ symporter), the level of dose reduction seen for blocking radioactive iodine is not expected for ${ }^{99} \mathrm{TcO}_{4}{ }^{-}$. Although the dietary iodine would block some of the uptake of Tc, the dose reducing effect of this blocking would not be as large as that for radioiodine because pertechnetate does not become organically bound in the thyroid and thus is not retained for months the way iodide is.

From the survey of the nuclear medicine literature, it is not possible to compute the effect of stable iodine in the diet on the dose per unit intake factors for ${ }^{99} \mathrm{Tc}$ without developing an improved biokinetic model for technetium. Specific experiments should be designed to quantitatively evaluate ${ }^{99} \mathrm{TcO}_{4}{ }^{-}$metabolism, excretion, and secretion, as well as to evaluate its chemical toxicity 


\subsection{Recommendations}

It is recommended that the ICRP reexamine its biokinetics models for Tc based on nuclear medicine data that have accumulated over the years. In particular, the ICRP ignores the lactation pathway, the enhanced concentration of Tc in breast and breast milk, and enhanced concentration of Tc (and I) in the salivary glands as well as in the thyroid. The ICRP should also explicitly incorporate the effect of stable iodine in the diet into both its models for iodine and technetium. The effect of concentration of Tc in breast milk needs further study for dosimetric implications to nursing infants whose mothers may ingest ${ }^{99} \mathrm{TcO}_{4}{ }^{-}$from groundwater sources. The ICRP should also investigate the possibility of enhanced concentration of both I and Tc in the nonlactating female breast.

To do these re-evaluations, new experiments designed specifically to evaluate these questions concerning the biokinetics of Tc and I are needed. 


\subsection{Acknowledgements}

The author wishes to thank Dade W. Moeller for extensive and very helpful discussions. The author also wishes to thank Calvin C. Ainsworth, Dominic A. Cataldo, and Bruce A. Napier for helpful discussions of technetium chemistry. The author also wishes to thank Paul S. Stansbury for review and suggestions. 


\title{
7.0 References
}

\author{
Reference List
}

1. Ahlgren L, S Ivarsson, L Johansson, S Mattsson, and B Nosslin. 1985. "Excretion of radionuclides in human breast milk after the administration of radiopharmaceuticals." J.Nucl.Med. 26(9):1085-1090.

2. Bohuslavizki KH, S Klutmann, W Brenner, J Mester, E Henze, and M Clausen. 1998. "Salivary gland protection by amifostine in high-dose radioiodine treatment: results of a double-blind placebo-controlled study." J.Clin.Oncol. 16(11):3542-3549.

3. Dunning DE, Jr. and G Schwarz. 1981. "Variability of Human Thyroid Characteristics and Estimates of Dose from Ingested I-131." Health Physics 40(5):661-675.

4. Harvey RP, DM Hamby, and RR Benke. 2003. "Age-specific uncertainty of the ${ }^{131}$ I ingestion dose conversion factor." Health Physics 84(3):334-343.

5. Hedrick WR, RN Di Simone, and RL Keen. 1986. "Radiation dosimetry from breast milk excretion of radioiodine and pertechnetate." J.Nucl.Med. 27(10):1569-1571.

6. International Commission on Radiological Protection (ICRP). 1975. Report of the Task Group on Reference Man. ICRP Pub. 23, Pergamon Press, Oxford.

7. International Commission on Radiological Protection (ICRP). 1993. "Age-Dependent Doses to Members of the Public from Intake of Radionuclides: Part 2 Ingestion Dose Coefficients. ICRP Publication No. 67." Annals of the ICRP 23(3/4).

8. International Commission on Radiological Protection (ICRP). 1995. "Age-Dependent Doses to Members of the Public from Intake of Radionuclides: Part 4 Inhalation Dose Coefficients. ICRP Publication No. 71." Annals of the ICRP 25(3-4).

9. International Commission on Radiological Protection (ICRP). 2002. "Basic Anatomical and Physiological Data for Use in Radiological Protection: Reference Values. ICRP Publication 89." Annals of the ICRP 32(34).

10. James AC. 2003. User Manual for IMBA Expert USDOE-Edition, Beta +, Version 3.0.64. ACJ \& Associates, Inc., Richland, Washington USA.

11. Langmuir D. 1997. Aqueous Environmental Geochemistry. Prentice-Hall, Inc., Upper Saddle River, New Jersey.

12. Meller J and W Becker. 1998. "Scintigraphic evaluation of functional thyroidal autonomy." Exp.Clin.Endocrinol.Diabetes 106 Suppl 4:S45-S51.

13. Moeller DW. 2003. Upper Bound Thyroid Dose Rate due to ${ }^{129}$ I Intake by People in the Town of Amargosa Valley, $N V$. Draft of 6/30/2003, Dade Moeller \& Associates, Richland, Washington.

14. Mountford PJ and AJ Coakley. 1989. "A review of the secretion of radioactivity in human breast milk: data, quantitative analysis and recommendations." Nucl.Med.Commun. 10(1):15-27.

15. National Cancer Institute. 1997. Estimated Exposures and Thyroid Doses Received by the American People from Iodine-131 in Fallout Following Nevada Atmospheric Nuclear Bomb Tests. Appendix 6: Metabolism 
and Dosimetry of ${ }^{131} I$. http://rex.nci.nih.gov/massmedia/Fallout/index.html, National Cancer Institute, Washington, DC.

16. National Council on Radiation Protection and Measurements (NCRP). 1993. Research Needs for Radiation Protection. NCRP Report No. 117, NCRP Publications, Bethesda, Maryland.

17. Petrich T, HJ Helmeke, GJ Meyer, WH Knapp, and E Potter. 2002. "Establishment of radioactive astatine and iodine uptake in cancer cell lines expressing the human sodium/iodide symporter."

Eur.J.Nucl.Med.Mol.Imaging 29(7):842-854.

18. Reinhardt MJ, S Hogerle, T Trupkovic, TM Krause, and E Moser. 1998. "Influence of urinary iodine excretion on thyroid technetium-99m pertechnetate uptake with and without TSH suppression: what happens when iodine supply increases?" Eur.J.Nucl.Med. 25(11):1475-1481.

19. Robertson DE, DA Cataldo, BA Napier, KM Krupka, and LB Sasser. 2003. Literature Review and Assessment of Plant and Animal Radionuclide Transfer Factors Used in Performance Assessment Modeling. NUREG/CR-6825 PNNL-14321, U.S. Nuclear Regulatory Commission, Washington, DC.

20. Rubow S, J Klopper, H Wasserman, B Baard, and M van Niekerk. 1994. "The excretion of radiopharmaceuticals in human breast milk: additional data and dosimetry." Eur.J.Nucl.Med. 21(2):144-153.

21. Stather JW and JR Greenhalgh. 1983. The Metabolism of Iodine in Children and Adults. NRPB-R140, National Radiological Protection Board, Chilton, Didcot, Oxon, UK.

22. U.S. Food and Drug Administration (FDA). 2001. Guidance. Potassium Iodide as a Thyroid Blocking Agent in Radiation Emergencies. http://www.fda.gov/cder/guidance/4825fnl.htm, U.S. Food and Drug Administration, Rockville, Maryland.

23. Van Sande J, C Massart, R Beauwens, A Schoutens, S Costagliola, JE Dumont, and J Wolff. 2003. "Anion selectivity by the sodium iodide symporter." Endocrinology 144(1):247-252. 